\title{
Fear Psychosis and Behavioral Changes Affecting Kids in War-Zones
}

\author{
Hasanbir Virk \\ Amity University, Noida, India
}

\begin{abstract}
Fear is the most natural and ancient feeling, the mankind is exposed since the beginning of the civilization and the existence of human beings. This feeling of wellbeing, your life and the survival of you and your loved ones is very common. All those who are exposed to the wars, riots, clash, and natural disaster are well aware of the feeling and as anybody have more or less experienced this feeling at some point of time in his/her life. But situation becomes worse when it comes to the kids in their growing age and specially those who are forced to live in the war zone among the fear of attacks in the habitat.
\end{abstract}

Key words: $\quad$ Fear Psychosis, War-Zones, Anxiety, Depression, Suicidal Emotions

\section{Introduction}

Fear is the most natural and ancient feeling, the mankind is exposed since the beginning of the civilization and the existence of human beings. This feeling of well being, your life and the survival of you and your loved ones is very common. All those who are exposed to the wars, riots, clash, and natural disaster are well aware of the feeling and as anybody have more or less experienced this feeling at some point of time in his/her life.

But situation becomes worse when it comes to the kids in their growing age and specially those who are forced to live in the war zone among the fear of attacks in the habitat. They are unable to respond being very young and vulnerable to the situation which force them to false prey and easy target in this situation. The fear of their loved one's life is evident if you explore the images of the war zone in Syria, Iraq and Afghanistan. Especially the most painful is to find very young kids are worst hit by these violent acts. These young kids are unable to protect them and are exposed to the circumstances where some of them have lost their parents, siblings - But these young kids are worst emotionally hit that they become blank and dumped to respond under the fear of their individual survival and also that till how long they will be lucky to survive. They are so young to understand who is right and who is wrong to make up their own personal opinion.

\section{The Long Term Threat}

The fragile conditions have been is well understood and exploited by the evil minds and those who fix their agenda to use these fallen kids to fulfill their foul play- These are spoon feed to fight the unknown enemy and their young mind is so delicate to differentiate between the right and wrong and they fail to understand the foul play of their mentor the terror mind. This situation is not only threat to the world peace but this is a opportunity to take pro active role to break this nexus to help these young minds to foul trap of dirty politics. The religion, caste, race has nothing to do with the well being of these innocent kids- As these are victim of the circumstances and now it becomes the duty of world civil society to protect the human rights and also to provide a peaceful world environment for their normal growth.

As looking at the problem primarily it looks like a situation of war and peace and we presume as once we subside the war, we will save the precious lives. But once we understand the real scenario of war and peace process we can make-out that among the major steps to establish peace, we fail to realize that by the time we will establish peace, The precious time to save these young minds will be lost, so all the peace keeping missions are never complete if they are deprived of well being mission specially designed for the kids in a war which are most vulnerable and needed immediate emotional, psychological treatment.

\section{Post War Impacts}

After the careful survey of the series of the events and their post-war impacts, it is well understood that the main symptoms of these kids in war zones are reported by the world media, activist and peace keepers are as follows -

- They are reported to be fallen and deprived of food, shelter and education besides their safety and survival as main issue. 
- They are worst hit emotionally and they are vulnerable to permanent changes in their behavior.

- They are prone to develop fear psychosis, anxiety, depression and even the suicidal emotions.

- They are prone to develop worst infections and diseases due to unhygienic environment they are forced to live.

- Survival becomes race for them for food and shelter becomes secondary which may kill their normal growth.

- They are deprived of education, love and affection which they deserve.

- They stop behaving like kids as they are overnight grown up, they understand the value of their relations and are stressed with the fear of losing their loved ones.

- The war zone itself gives enough reasons to feel stress, fear and anxiety. These kids stop behaving as kids, they act to search for their survival like any adult in the war zone, they search for the food, safe shelter and they even take care of the young and elderly relations living with them.

\section{Conclusion}

Since the inception of the united-nations and the vision to maintain world-wide peace, different agencies were formed to look after the human rights and wellbeing of the civil society and to protect the human beings from the possible war, riots and clashes. But the foul plays and politics of religion, race and terror keep knocking the doors of the nations with different names and ideologies. But one thing is common that they disrupt the normal living of the civilians and they put a permanent dent in the memories, history of the nations. Kids which are most precious are soft target of these terror minds who try to inject their dirty ideology in young minds to establish their evil ideology on main frame. This theory is well understood now and it is duty of the world leaders to make a policy to deal carefully with these war and terror-zones and kids of the region needs to be evacuated and carefully handled with love and affection they deserve with proper care for their education for their safe future.

\section{References}

[1]. Ayesha Kadir, Sherry Shenoda, Jeffrey Goldhagen, Shelly Pitterman (2018), The Effects of Armed

\section{Conflict on Children, SECTION ON INTERNATIONAL CHILD HEALTH}

[2]. Chan M, Lake A. Statement on Attacks on Medical Facilities and Personnel in the Syrian Arab Republic. Geneva, Switzerland: World Health Organization; 2016

[3]. David W. Mays (2016), Exit Iraq, Business Press.

[4]. David W. Mays (year- 2016), Tyrants of Tikrit, Business Press.

[5]. Linton JM, Griffin M, Shapiro AJ; Council on Community Pediatrics. Detention of immigrant children. Pediatrics. 2017;139(5):e20170483pmid:28289140

[6]. Malemo Kalisya L, Lussy Justin P, Kimona C, et al. Sexual violence toward children and youth in war-torn eastern Democratic Republic of Congo. PLoS One. 2011;6(1):e15911pmid:21267467

[7]. Mousavi B, Soroush MR, Masoumi M, et al. Epidemiological study of child casualties of landmines and unexploded ordnances: a national study from Iran. Prehosp Disaster Med. 2015;30(5):472-477pmid:26374671

[8]. Organization for the Prohibition of Chemical Weapons. Report of the OPCW fact-finding mission in Syria regarding an alleged incident in Saraqib, Syrian Arab Republic on February 4, 2018. 2018. Available at: https://www.opcw.org/fileadmin/OPCW/S_series/2 018/en/s-1626-2018_e_.pdf. Accessed May 22, 2018

[9]. Pediatrics Dec 2018, 142 (6) e20182586; DOI: 10.1542/peds.2018-2586

[10]. SANYA DHINGRA (2017), Manmohan Singh didn't speak much, but did as much to fight terror: former NSA Narayanan, The Print, https://theprint.in/defence/manmohan-singh-fightterror-former-nsa/22388/

[11]. United Nations Environment Programme. Environmental Assessment of the Gaza Strip Following the Escalation of Hostilities in December 2008 - January 2009. Nairobi, Kenya: United Nations Environment Programme; 2009

[12]. United Nations High Commissioner for Refugees. Global trends: forced displacement in 2017. http://www.unhcr.org/globaltrends2017/. Accessed June 29, 2018

[13]. Data and facts from US Peace keeping mission in Iraq, Syria and Afghanistan wars.

[14]. Multiple Media Reports of CNN, ZEE News and other national news publishers. 